\title{
IMPLEMENTASI PEMBELAJARAN ENTREPRENEURIAL DALAM PENDIDIKAN SENI RUPA
}

\author{
Moeljadi Pranata
}

Universitas Negeri Malang

\begin{abstract}
This study aims to produce a model of entrepreneurial learning in the field of art education in secondary schools. For this purpose teachers have developed textbooks; the books are designed in accordance with entrepreneurial learning cycle. The study found that art education teaching materials have been designed according to the specific learning strategies potential to improve the entrepreneurial mindset of learners. The results of this study has offered a strategic value to develop entrepreneurship education in Indonesia, especially when considering that the results of this research offers the potential to be extended to other fields and subjects in terms of types and levela of education.
\end{abstract}

Keywords: entrepreneurial learning, visual art education

\begin{abstract}
Abstrak: Penelitian ini bertujuan untuk menghasilkan model pembelajaran kewirausahaan di sekolah menengah. Untuk tujuan ini dikembangkan buku ajar yang dikembangkan oleh guru; buku ini dirancang sesuai dengan learning cycle entrepreneurial. Studi ini menemukan bahwa buku ajar pendidikan seni yang dirancang sesuai dengan strategi pembelajaran tertentu memiliki potensi untuk meningkatkan pola pikir kewirausahaan pada siswa. Hasil penelitian ini memiliki nilai strategis untuk pengembangan pendidikan kewirausahaan di Indonesia. Utamanya ketika mempertimbangkan bahwa hasil penelitian ini memiliki potensi untuk diperluas ke bidang dan mata pelajaranan-mata pelajaran lain pada jenis dan tingkat pendidikan yang beragam.
\end{abstract}

Kata Kunci: pembelajaran entrepreneurial, pendidikan seni rupa

Kualitas pendidikan di negara berkembang tidak sebagaimana yang diharapkan. Pada umumnya, di negara-negara berkembang pendidikan hanya berfokus pada belajar hafalan. Selain itu, sistem pendidikan tidak secara aktif mendorong siswa untuk berpikir secara mandiri. Sistem pendidikan masih mengabaikan pentingnya mengembangkan pola pikir kreatif. Sistem seperti ini jelas tidak sejalan dengan fungsi pendidikan sebagai alat untuk pribadi (UNESCO 1996, 2004).

Secara umum, jika ditinjau dari rendahnya angka indeks pembangunan manusia (human development index) serta tingginya angka pengangguran, dapat diketahui bahwa pendidikan di Indonesia belum berlangsung secara berkualitas sebagaimana yang 
diharapkan. Mengingat ancaman dan peluang terkait dengan kualitas sumber daya manusia dan daya saing bangsa, belajar untuk era sekarang mestinya tidak cukup jika berhenti dalam tahapan memahami. Tahapan harus dilanjutkan ke proses menghasilkan. Siswa mestinya terlatih untuk memfungsikan pengetahuan dan keterampilan yang telah dimiliki untuk dapat menghasilkan ciptaan yang bernilai. Sejalan dengan hal tersebut, perlu dieksplorasi caracara yang memungkinkan para siswa dapat memperoleh kompetensi sesuai dengan tujuan instruksional menurut mata pelajaran yang dipelajarinya sekaligus memperoleh kompetensi yang terkait dengan kemampuan menghasilkan gagasan dan produk yang kreatif, inovatif, dan bernilai tambah yang dapat dihargai dan diterima oleh orang lain. Hal ini sejalan dengan kompetensi pada setiap wirausahawan atau entrepreneur (Bolton \& Thomson, 2005; Swedberg. 2006).

Bolton \& Thompson (2005) mendefinisikan entrepreneur sebagai seseorang yang terbiasa menciptakan dan berinovasi berdasarkan peluang yang ada untuk membangun sesuatu yang bernilai yang dapat diterima dan diakui oleh masyarakat. Entrepreneur sebagai sebuah pola pikir dapat dipandang sebagai sebuah kerangka berpikir untuk berinovasi sehingga hasil inovasi tersebut dapat diterima dan dihargai oleh orang lain. Kerangka berpikir yang demikian, menurut Dyers (2007) berupa sintaks yang terdiri atas kegiatan mengeksplorasi, merancang, mengeksekusi rancangan, mengomunikasikan, dan merefleksi proses dan produk yang telah dihasilkan serta memberikan rekomendasi bagi perbaikan selanjutnya. Dalam konteks pembelajaran, sintaks tersebut berlangsung secara berurutan serta berbentuk learning cycle (Kolb \& Kolb, 2006).

Penelitian ini menerapkan model pembelajaran entrepreneurial dengan menerapkan sintaks kerangka pikir entrepreneurial yang berpusat pada aktivitas siswa untuk mengorganisasikan, mengelola, dan menyampaikan isi pembelajaran pada bahan ajar pendidikan seni rupa. Strategi pembelajaran diacukan sebagai penataan cara-cara sehingga terwujud suatu urutan langkah-langkah prosedural yang dapat dipakai untuk mencapai tujuan yang ditetapkan (Reigeluth dkk, 2007). Penataan cara-cara pada bahan ajar yang dikembangkan mengacu pada tujuan yang akan dicapai siswa yaitu (a) kompetensi menurut mata pelajaran pendidikan seni rupa dan (b) kompetensi pola pikir entrepreneurial. Dalam konteks ini, belajar dalam pendidikan seni rupa tidak hanya sekedar untuk menghasilkan karya seni, namun juga terbiasa memecahkan masalah sejalan dengan pola pikir entrepreneurial.

Pembiasaan untuk menerapkan pola pikir entrepreneurial pada pembelajaran seni rupa berdampak positif bagi pengembangan sumberdaya manusia yang memiliki kepekaan terhadap peluang, kreatif, inovatif, berani menghadapi resiko, bersifat terbuka, dan produktif (Beckman, 2007; Beckman \& Essig, 2012). Penerapan strategi pembelajaran entrepreneurial pada mata pelajaran seni pada gilirannya diprediksi akan dapat meningkatkan jumlah entrepreneur di Indonesia yang masih rendah. Seperti diketahui, pertumbuhan enterpreneur selain dapat menampung tenaga kerja, pada gilirannya juga dapat menciptakan kesejahteraan masyarakat secara luas. Ini sejalan dengan pendapat McClelland (1999), bahwa suatu negara akan maju jika terdapat entrepreneur sedikitnya $2 \%$ dari jumlah penduduk negara tersebut. Saat ini jumlah entrepreneur di Indonesia baru sekitar 0,18\% dari jumlah penduduk di Indonesia, sementara itu Singapura memiliki 7,2\% entrepreneur dari jumlah penduduknya (Global Entrepreneurship Monitor, 2005). Jadi tidaklah mengherankan jika pendapatan perkapita Singapura puluhan kali lebih tinggi daripada Indonesia. 
Beberapa studi telah menegaskan bahwa meningkatnya jumlah entrepreneur juga akan berdampak pada meningkatnya pendirian perusahaan baru (misalnya Hatten \& Ruhland, 1995). Meningkatnya perusahaan baru berdampak pada meningkatnya perekonomian negara. Kebangkitan ekonomi China yang dipicu oleh munculnya banyak perusahaan baru dapat dijadikan contoh untuk kasus ini. Sejak negara ini menghapus monopoli negara dan membuka peluang sebesar-besarnya bagi warga negara untuk berwirausaha maka ledakan jumlah perusahaan baru meningkat secara drastis (Ahlstrom \& Ding, 2014). Hal ini berdampak positif pada perkembangan pesat perekonomian negara tersebut.

Studi yang dilakukan oleh McMullan \& Long (1987) menyimpulkan bahwa sebuah dukungan sistem usaha berdasarkan pendidikan entrepreneur dapat mengakibatkan tingkat pengangguran yang lebih rendah. Selain perusahaan-perusahaan yang bermunculan akan memperluas lapangan kerja baru, pribadi berkarakter entrepreneurial yang dibentuk akan terbiasa untuk hidup secara mandiri dan produktif. Studi yang dilakukan Acs (1996) melaporkan bahwa para entrepreneur pada perusahaan-perusahaan kategori usaha kecil dan menengah kebanyakan merupakan orang-orang biasa, namun memiliki pola pikir entrepreneurial yang tajam. Para entrepreneur tersebut dikenal ulet dan tahan bantingan. Kemampuan mereka menghadapi krisis ekonomi menjelang abad 21 telah membuktikan bahwa pribadi dengan karakter entrepreneurial seperti itu cukup tangguh dalam menghadapi tekanan serta tangkas dalam memanfaatkan peluang.

Dalam pelaksanaannya, penerapan strategi pembelajaran entrepreneurial ini tidak mengurangi keberadaan kurikulum yang telah ditetapkan untuk dilaksanakan di sekolahsekolah Indonesia. Sebagai penguat kurikulum yang telah ada, strategi pembelajaran tersebut justru akan memperkaya hasil belajar siswa. Selain siswa akan memperoleh kompetensi sesuai dengan kompetensi-kompetensi dasar yang telah ditetapkan oleh kurikulum, siswa juga akan memperoleh pembangunan karakter yaitu memiliki kerangka pikir (mindset) entrepreneurial. Ini terjadi karena pola pembelajaran yang digunakan mengacu pada lima tahapan pola berpikir entrepreneurial sebagaimana telah dijelaskan sebelumnya. Pola pembelajaran yang demikian terjadi sebagai implikasi dari strategi pembelajaran yang sebelumnya telah dirancang dengan seksama oleh para guru mereka.

Strategi pengorganisasian, pengelolaan, dan penyampaian bahan ajar pendidikan seni rupa dalam penelitian ini dirancang menurut lima tahapan, yaitu mengeksplorasi (exploring), merencanakan (planning), mengeksekusi rencana (doing), mengomunikasikan (communicating), dan merefleksi (reflecting). Dalam tahap mengeksplorasi (exploring), siswa dilatih untuk mencari dan menggali informasi, fakta-fakta, dan masalah agar dapat menemukan hal pokok yang harus dipelajari secara lebih fokus. Hal pokok tersebut akan mengarahkan mereka pada kemungkinan-kemungkinan untuk berinovasi. Proses ini juga memberi kesempatan bagi siswa untuk mempelajari pola, sistem atau konsep yang ada. Pada tahap mengeksplorasi, peran guru ialah mengarahkan siswa dengan desain tahapan belajar yang sistematis dan bertahap tanpa mengurangi kesempatan bagi siswa untuk berlatih menemukan kesempatan. Guru memberi kesempatan siswa membuat interpretasi dan mencari hubungan satu konsep dangan konsep lain serta mengambil simpulan.

Pada tahap merencanakan (planning), siswa mengembangkan fokus yang telah ditemukan serta memahami model atau sistem yang ada. Kegiatan ini mengarahkan siswa untuk mencari inspirasi guna menemukan model atau sistem baru. Pengertian baru tidak selalu $100 \%$ baru karena itu mungkin saja ada beberapa faktor yang perlu diganti dengan apa yang ditemukan atau diciptakan sendiri. Berdasarkan model yang sudah ada, siswa mengembangkan hal yang baru. Ini merupakan salah satu prinsip dalam menciptakan 
inovasi. Dasar dari langkah-langkah pada tahap kedua ini ialah sikap kreatif dan berani mencoba yang dituangkan ke dalam sebuah rencana kerja. Tahap merencanakan akan melatih siswa untuk mempertimbangkan masalah waktu, tujuan atau target yang akan dicapai, prosedur kerja serta antisipasi tantangan yang mungkin akan ditemukan. Pada tahap merencanakan, guru berperan sebagai advisor agar siswa dapat membuat rencana produk dan rencana kerja sesuai dengan target yang harus dicapai. Untuk itu, teknik-teknik pemberian inspirasi perlu dikuasai oleh para guru.

Kegiatan pada tahap ketiga, mengeksekusi rencana (doing), berfokus pada proses pelaksanaan rencana yang telah disusun oleh siswa. Fokusnya ialah melakukan tindakan untuk dapat menghasilkan sesuatu yang bernilai. Penekanan tahap ini adalah melatih siswa untuk bekerja secara kolaboratif dan bekerja berdasarkan rencana. Siswa berlatih untuk secara konsisten dengan kerangka waktu dan tahapan yang ditetapkan serta memperhatikan standar perilaku kerja yang seharusnya. Hasil dari kegiatan ini ialah sebuah produk inovatif yang siap untuk dikomunikasikan agar dapat diterima dan dihargai. Maka tantangan pada tahap berikutnya bagi siswa ialah bagaimana mengomunikasikan hasil kerja tersebut kepada orang lain agar hasil kerjanya dapat diterima dan memperoleh penghargaan. Tahap mengomunikasikan (communicating) ini sangat perlu agar siswa memiliki pengalaman yang bermakna untuk berlatih keterampilan berkomunikasi dan mengenal respon-respon dari kelompok sasaran. Aspek lain yang akan tumbuh dalam kegiatan ini ialah perlunya pembangunan rasa percaya diri dan pengetahuan tentang subject matter. Di tahap komunikasi ini guru berperan sebagai sparing partner bagi siswa; ia dituntut terampil untuk memberikan pancingan-pancingan agar cara siswa berkomunikasi fokus dan meyakinkan sasarannya.

Langkah pada tahap terakhir, yaitu merefleksi (reflecting) bertujuan agar siswa dapat mengetahui atau mengenal kemajuan belajarnya sendiri atau self competency. Pada tahap ini, guru dapat berperan sebagai kritikus yang memberikan masukan-masukan agar siswa menjadi reflektif dan mengenali hal yang perlu diperhatikan. Tahap merefleksi ini merupakan hal yang penting dalam proses belajar. Lewat kegiatan ini siswa dapat mengenali kelemahan dan kekuatan diri mereka sendiri. Kegiatan tersebut pada gilirannya akan mendorong siswa untuk mampu mengidentifikasi hal-hal yang telah dicapai dan aspek apa yang akan menjadi target berikutnya. Pola kegiatan pembelajaran yang demikian akan membantu siswa untuk mengembangkan pola belajar self directed learning. Jika siswa bisa belajar apa yang seharusnya dipelajarinya, sebenarnya mereka telah belajar bagaimana seharusnya belajar - learn how to learn (Duffy \& Jonassen, 1992).

Dengan mengalami siklus belajar yang terdiri atas 5 tahapan tersebut maka melalui belajar dan pembelajaran pendidikan seni rupa akan terbangun pola bereksplorasi dan perilaku mencipta. Dalam konteks tersebut, pembelajaran akan menjadi ajang bagi siswa untuk mencari, menemukan, mencipta, dan "menjual" hasil kerjanya. Pola belajar tidak lagi menerima materi tapi proses menghasilkan inovasi. Mengajar bukan lagi memberi atau menyalurkan informasi, namun mengambil atau mengeluarkan potensi dari diri siswa serta mengkondisinya agar siswa dapat dan terbiasa mengoptimalkan potensi tersebut untuk menghasilkan sesuatu inovasi (Longworth, 1999).

\section{METODE}

Pengembangan buku ajar ini menggunakan Model 4D yang meliputi tahap pendefinisian (define), perancangan (design), pengembangan (develop), serta tahap 
pendeseminasian (disseminate). Prosedur penelitian pengembangan secara utuh disajikan oleh Tabel 1. Proses analisis masalah dilakukan pada tahap define. Analisis tersebut melalui lima tahapan, antara lain: (a)front end analysis, (b) learner analysis, (c) task analysis, (d) concept analysis, dan (e) specifying of instructional objectives. Dalam tahapan ini dilakukan kegiatan penetapan dan penentuan kebutuhan. Proses analisis kebutuhan menggunakan proses analisis masalah yang akan dikaji dalam beberapa tahapan. Bertolak dari kegiatan pengembangan pada tahap define tersebut dihasilkan beberapa luaran antara lain (a) konsep pendekatan pembelajaran entrepreneurial dan (b) hasil analisis kompetensi dan indikatorindikator pencapaian kompetensi.

Tahap design berupa proses pembuatan draft atau rancangan setelah spesifikasi produk ditentukan dalam proses define. Analisis design meliputi empat tahapan, antara lain (a) criteriontest construction, (b) media selection, (c) format selection, dan (d) initial design. Sementara itu pada tahap develop dilakukan proses revisi draft atau rancangan. Dalam proses ini, umpan balik digunakan sebagai evaluasi agar menjadi versi yang benar-benar efektif. Analisis develop melalui dua tahapan, antara lain (a) expert appraisal dan (b) developmental testing. Proses pematangan bahan ajar ini perlu dilakukan agar produk yang dikembangkan tersebut benar-benar efektif. Tahap develop terdiri dua atas dua bagian, yaitu expert appraisal dan developmental testing.

Tahap terakhir, disseminate, merupakan proses finalisasi seluruh kegiatan penelitian dan pengembangan ini. Dalam konteks ini produk pengembangan dapat dikatakan memasuki proses final apabila hasil uji coba menunjukkan nilai yang konstan dan tim ahli merekomendasikan komentar yang positif. Proses disseminate dilakukan sebelum produk disebarluaskan. Kegiatan disseminate terdiri atas tiga tahapan antara lain (a) validation testing, packaging, (b) diffusion, dan (c) adoption.

\begin{tabular}{|c|c|c|c|c|}
\hline Komponen & Define & Design & Develop & Disseminate \\
\hline Masukan & $\begin{array}{l}\text { - Analisis siswa } \\
\text { - Analisis kebutuhan } \\
\text { - Analisis tugas } \\
\text { - Analisis kensep } \\
\text { - Analisis standar isi }\end{array}$ & $\begin{array}{l}\text { - Konsep KPE pada } \\
\text { PSB } \\
\text { - SK/KI dan KD } \\
\text { - Indikator } \\
\text { - Analisis siswa } \\
\text { - Konstruksi kaiteria } \\
\text { tes }\end{array}$ & $\begin{array}{l}\text { - Draft perangkat } \\
\text { pembelajaran } \\
\text { - Analisis siswa } \\
\text { - Konstruksi kriteria } \\
\text { tes }\end{array}$ & $\begin{array}{l}\text { - Merencana danme- } \\
\text { rancang instrumen } \\
\text { ujicoba }\end{array}$ \\
\hline Proses & $\begin{array}{l}\text { - Mengkaji konsep } \\
\mathrm{KPE} \\
\text { - Analisis SK/KI dan } \\
\mathrm{KD} \\
\text { - Analisis indikator }\end{array}$ & $\begin{array}{l}\text { - Merencara danme- } \\
\text { rancang perangkat } \\
\text { pembelajaran }\end{array}$ & $\begin{array}{l}\text { - Merencana danme- } \\
\text { ranceng instrumen } \\
\text { validasi } \\
\text { - Validasi draft pe- } \\
\text { rangkat pembcla- } \\
\text { jaran }\end{array}$ & $\begin{array}{l}\text { - Mengembangkan } \\
\text { instrumen ujicoba } \\
\text { - Ujicoba lapangan } \\
\text { - Pengemasan pe- } \\
\text { rangkat pembela- } \\
\text { jaran }\end{array}$ \\
\hline Keluaran & $\begin{array}{l}\text { - Konsep KPE pada } \\
\text { PSB } \\
\text { - SK/KI dan KD } \\
\text { - Indikator }\end{array}$ & $\begin{array}{l}\text { - Draft perangkat pem- } \\
\text { belajaran }\end{array}$ & $\begin{array}{l}\text { - Hasil validasi pe- } \\
\text { rangkat pembela- } \\
\text { jaran }\end{array}$ & $\begin{array}{l}\text { - Validasi buku ajar } \\
\text { - Buku ajar final }\end{array}$ \\
\hline
\end{tabular}

Tabel 1. Prosedur Penelitian (Pranata, 2010)

\section{HASIL DAN PEMBAHASAN}

Buku ajar yang telah dihasilkan divalidasi oleh tiga orang pakar sebagai validator. Validator buku ajar ini terdiri atas dua orang doktor pendidikan yang menjadi dosen di perguruan tinggi serta seorang guru senior di bidang Pendidikan Seni Rupa yang 
berpengalaman mengembangkan kurikulum di sekolah-sekolah. Penilaian buku ajar oleh tim pakar menggunakan rubrik yang terdiri atas rubrik penilaian kelayakan isi buku ajar, rubrik penilaian kebahasaan buku ajar, rubrik kelayakan penyajian materi, dan rubrik kelayakan penyajian pembelajaran. Masing-masing rubrik dirinci ke dalam kriteriakriteria yang dinilai, masing-masing kriteria diberi skor 1 (kurang) sampai dengan 3 (baik).

\begin{tabular}{|c|c|c|c|c|c|c|c|c|}
\hline \multirow[t]{2}{*}{ Kelayakan Isi Buku Ajar } & \multicolumn{3}{|c|}{ Validator } & \multirow[t]{2}{*}{$\Sigma$} & \multirow[t]{2}{*}{$\mathbf{R}$} & \multirow[t]{2}{*}{ Kategori } & \multicolumn{2}{|c|}{ Reliabilitas } \\
\hline & $\mathbf{V}_{1}$ & $\mathbf{V}_{\mathbf{2}}$ & $\mathbf{V}_{\mathbf{3}}$ & & & & A & D \\
\hline Akurasi Materi & & & & 23 & 2.6 & Baik & & \\
\hline 1 Kebenaran dan ketepatan fakta/konsep & 2 & 3 & 2 & 7 & 2.3 & Cukup & 0.7 & 0.3 \\
\hline $\begin{array}{l}2 \text { Kebenaran dan ketepatan teori, prinsip, } \\
\text { hukum }\end{array}$ & 3 & 2 & 3 & 8 & 2.7 & Baik & 0.7 & 0.3 \\
\hline $\begin{array}{l}3 \text { Kebenaran dan ketepatan proses/metode } \\
\text { ilmiah }\end{array}$ & 3 & 2 & 3 & 8 & 2.7 & Baik & 0.7 & 0.3 \\
\hline Kemutakhiran Materi & & & & 13 & 2.2 & Cukup & & \\
\hline 1 Materi sesuai dengan perkembangan ilmu & 2 & 2 & 2 & 6 & 2.0 & Cukup & 1.0 & 0.0 \\
\hline $\begin{array}{l}2 \text { Keterkinian/ketermasaan fitur (contoh- } \\
\text { contoh) }\end{array}$ & 3 & 2 & 2 & 7 & 2.3 & Cukup & 0.7 & 0.3 \\
\hline Mengandung Wawasan Entrepreneurship & & & & 15 & 2.5 & Baik & & \\
\hline 1 Menumbuhkan semangat kewirausahaan & 2 & 3 & 3 & 8 & 2.7 & Baik & 1.0 & 0.0 \\
\hline 2 Membiasakan berpola pikir entrepreneurial & 3 & 3 & 3 & 9 & 3.0 & Baik & 1.0 & 1.0 \\
\hline Merangsang Produktivitas & & & & 15 & 2.5 & Baik & & \\
\hline 1 Menumbuhkan semangat daya saing & 3 & 3 & 3 & 9 & 3.0 & Baik & 1.0 & 0.0 \\
\hline 2 Mendorong etos kerja produktif & 2 & 2 & 2 & 6 & 2.0 & Cukup & 1.0 & 0.0 \\
\hline Merangsang Kreativitas dan Inovasi & & & & 15 & 2.5 & Baik & & \\
\hline 1 Memicu eksplorasi daya cipta (kreativitas) & 2 & 3 & 2 & 7 & 2.3 & Cukup & 0.7 & 0.3 \\
\hline Mendorong berinovasi untuk nilai tambah & 2 & 3 & 3 & 8 & 2.7 & Baik & 0.7 & 0.3 \\
\hline Mengembangkan Kecakapan Hidup & & & & 14 & 2.3 & Cukup & & \\
\hline $\begin{array}{l}1 \text { Mengembangkan } \\
\text { akademik/vokasional }\end{array}$ & 3 & 2 & 2 & 7 & 2.3 & Cukup & 0.7 & 0.3 \\
\hline 2 Mengembangkan kecakapan sosial & 3 & 2 & 2 & 7 & 2.3 & Cukup & 0.7 & 0.3 \\
\hline
\end{tabular}

Tabel 2. Rangkuman Hasil Penilaian oleh Pakar: Kelayakan Isi Buku Ajar

Kriteria penilaian pada rubrik kelayakan isi materi buku ajar terdiri atas (a) akurasi isi materi, (b) kemutakhiran isi materi, (c) mengandung wawasan entrepreneurship, (d) merangsang produktivitas, (e) merangsang kreativitas dan inovasi, serta (f) mengembangkan kecakapan hidup. Masing-masing kriteria dirinci lagi ke dalam 2 sampai 3 subkriteria penilaian.

Rangkuman hasil penilaian validator mengenai kelayakan isi buku ajar disajikan dalam Tabel 2. Hasil penilaian kelayakan pakar untuk aspek kelayakan isi menunjukkan rerata skor akurasi materi 2,6 (baik), kemutakhiran materi 2,2 (cukup), mengandung wawasan kewirausahaan 2,5 (baik), merangsang produktivitas 2,5 (baik), merangsang kreativitas dan inovasi 2,5 (baik), dan mengembangkan kecakapan hidup 2,3 (cukup). Secara umum dapat disimpulkan bahwa kelayakan isi buku ajar berkategori cukup $(2,4)$.

Kriteria penilaian untuk kelayakan kebahasaan terdiri atas (a) pesan yang disampaikan mudah dipahami peserta didik, (b) struktur kalimat efektif, (c) kebakuan istilah, dan (d) kesalahan pengetikan. Hasil penilaian kelayakan pakar berdasarkan Tabel 3 untuk aspek 
kelayakan kebahasaan, rerata skor pesan yang disampaikan mudah dipahami peserta didik 2,3 (cukup), struktur kalimat efektif 2.0 (cukup), kebakuan istilah 3.0 (baik), dan kesalahan pengetikan 1.7 (kurang). Secara umum dapat disimpulkan bahwa kelayakan kebahasaan buku ajar berkategori cukup $(2,3)$.

\begin{tabular}{|c|c|c|c|c|c|c|c|c|}
\hline \multirow[t]{2}{*}{ Kelayakan Kebahasaan } & \multicolumn{3}{|c|}{ Validator } & \multirow[t]{2}{*}{$\Sigma$} & \multirow[t]{2}{*}{$\mathbf{R}$} & \multirow[t]{2}{*}{ Kategori } & \multicolumn{2}{|c|}{ Reliabilitas } \\
\hline & $\mathbf{V}_{\mathbf{1}}$ & $V_{2}$ & $V_{3}$ & & & & A & $\mathrm{D}$ \\
\hline Kebahasaan & & & & 27 & 2.3 & Cukup & & \\
\hline $\begin{array}{l}1 \text { Pesan yang disampaikan mudah dipahami } \\
\text { siswa }\end{array}$ & 3 & 2 & 2 & 7 & 2.3 & Cukup & 0.7 & 0.3 \\
\hline 2 Struktur kalimat efektif & 2 & 2 & 2 & 6 & 2.0 & Cukup & 1.0 & 0.0 \\
\hline Kebakuan istilah & 3 & 3 & 3 & 9 & 3.0 & Baik & 1.0 & 1.0 \\
\hline 4 Salah ketik & 1 & 2 & 2 & 5 & 1.7 & Kurang & 0.3 & 0.3 \\
\hline
\end{tabular}

Tabel 3. Rangkuman Hasil Penilaian oleh Pakar: Kelayakan Kebahasaan

Kriteria penilaian untuk kelayakan penyajian materi buku ajar terdiri atas (a) konsistensi sistematika isi materi, (b) keruntutan sajian konsep dan prosedur, (c) kesesuaian ilustrasi (gambar, tabel) dengan materi, (d) kemenarikan paparan materi ajar, (e) kelengkapan sumber pustaka. Bertolak dari rangkuman hasil perhitungan pada penilaian validator tentang kelayakan kebahasaan buku ajar seperti yang disajikan oleh Tabel 4 dapat diketahui beberapa informasi sebagai berikut. Kelayakan penyajian buku ajar untuk aspek konsistensi sistematika isi materi 2,7 (baik), (b) keruntutan sajian konsep dan prosedur 2,7 (baik), kesesuaian ilustrasi (gambar, tabel) dengan materi 2,7 (baik), kemenarikan paparan materi ajar 2,7 (baik), dan kelengkapan sumber pustaka 2,3 (cukup). Dapat disimpulkan bahwa secara umum kelayakan penyajian materi buku ajar berkategori baik $(2,6)$.

\begin{tabular}{|c|c|c|c|c|c|c|c|c|}
\hline \multirow{2}{*}{ Kelayakan Penyajian Buku Ajar } & \multicolumn{3}{|c|}{ Validator } & \multirow{2}{*}{$\Sigma$} & \multirow{2}{*}{$\mathbf{R}$} & \multirow{2}{*}{ Kategori } & \multicolumn{2}{|c|}{ Reliabilitas } \\
\hline & $\mathbf{V}_{1}$ & $\mathbf{V}_{2}$ & $V_{3}$ & & & & A & D \\
\hline Penyajian Materi Buku Ajar & & & & 39 & 2.6 & Baik & & \\
\hline 1 Konsistensi sistematika isi materi & 2 & 3 & 3 & 8 & 2.7 & Baik & 1.0 & 0.0 \\
\hline 2 Keruntutan sajian konsep dan prosedur & 3 & 2 & 3 & 8 & 2.7 & Baik & 0.7 & 0.3 \\
\hline $\begin{array}{lr}3 \text { Kesesuaian ilustrasi (gambar, tabel) } \\
\text { dengan materi }\end{array}$ & 2 & 3 & 3 & 8 & 2.7 & Baik & 1.0 & 0.0 \\
\hline 4 Kemenarikan paparan materi ajar & 2 & 3 & 3 & 8 & 2.7 & Baik & 1.0 & 0.0 \\
\hline $5 \quad$ Kelengkapan sumber pustaka & 3 & 2 & 2 & 7 & 2.3 & Cukup & 0.7 & 0.3 \\
\hline
\end{tabular}

Tabel 4. Rangkuman Hasil Penilaian oleh Pakar: Kelayakan Penyajian Materi Buku Ajar

Kriteria penilaian untuk kelayakan penyajian pembelajaran terdiri atas (a) berpusat pada kegiatan siswa, (b) merangsang siswa untuk belajar mandiri, (c) menggunakan pendekatan entrepreneurial, (d) memberi contoh-contoh konkret berdasarkan kehidupan nyata sehari-hari, (e) penyajian bersifat komunikatif-interaktif, dan (f) menciptakan umpan balik untuk evaluasi diri. Bertolak dari rangkuman hasil perhitungan pada penilaian para pakar tentang kelayakan pembelajaran seperti yang disajikan oleh Tabel 5 dapat diketahui beberapa informasi sebagai berikut. Kelayakan penyajian pembelajaran untuk aspek berpusat pada kegiatan siswa 3,0 (baik), merangsang siswa untuk belajar mandiri 2,7 (baik), menggunakan pendekatan entrepreneurial 2,7 (baik), memberi contoh-contoh konkret berdasarkan kehidupan nyata sehari-hari 2,3 (cukup), penyajian bersifat komunikatifinteraktif 2,3 (cukup), dan menciptakan umpan balik untuk evaluasi diri 2,3 (cukup). Rerata skor untuk kelayakan penyajian pembelajaran 2,6 sehingga dapat disimpulkan bahwa secara umum kelayakannya berkategori baik. 
Secara umum penilaian untuk seluruh aspek kelayakan buku ajar oleh pakar yang dinilai mendapatkan penilaian minimal cukup dari para penelaah tersebut tingkat validitasnya sebesar 2.3 berkategori baik dengan reliabilitas sebesar 77,01\% berkategori baik. Hal ini dapat diartikan bahwa untuk seluruh aspek yang dinilai pada buku ajar siswa, persentase untuk mendapatkan penilaian minimal 2 atau dikategorikan cukup. Meskipun demikian untuk kasalahan ketik ada satu validator yang memberikan skor 1 .

\begin{tabular}{|c|c|c|c|c|c|c|c|c|}
\hline \multirow{2}{*}{ Kelayakan Penyajian Buku Ajar } & \multicolumn{3}{|c|}{ Validator } & \multirow{2}{*}{$\Sigma$} & \multirow{2}{*}{$\mathbf{R}$} & \multirow{2}{*}{ Kategori } & \multicolumn{2}{|c|}{ Reliabilitas } \\
\hline & $V_{1}$ & $V_{2}$ & $V_{3}$ & & & & A & D \\
\hline Penyajian Pembelajaran & & & & 46 & $\begin{array}{l}2 . \\
6\end{array}$ & Baik & & \\
\hline Berpusat pada kegiatan peserta didik & 3 & 3 & 3 & 9 & $\begin{array}{l}3 . \\
0\end{array}$ & Baik & $\begin{array}{l}1 . \\
0\end{array}$ & 0.0 \\
\hline $\begin{array}{l}2 \text { Merangsang peserta didik untuk belajar } \\
\text { mandiri }\end{array}$ & 2 & 3 & 3 & 8 & $\begin{array}{l}2 . \\
7\end{array}$ & Baik & $\begin{array}{l}0 . \\
7\end{array}$ & 0.3 \\
\hline 3 Menggunakan pendekatan entrepreneurial & 3 & 2 & 3 & 8 & $\begin{array}{l}2 . \\
7\end{array}$ & Baik & $\begin{array}{l}0 . \\
7\end{array}$ & 0.3 \\
\hline $\begin{array}{l}4 \text { Memberi contoh konkret berdasarkan } \\
\text { kehidupan nyata }\end{array}$ & 3 & 2 & 2 & 7 & $\begin{array}{l}2 . \\
3\end{array}$ & Cukup & $\begin{array}{l}0 . \\
7\end{array}$ & 0.3 \\
\hline 5 Penyajian bersifat komunikatifinteraktif & 3 & 2 & 2 & 7 & $\begin{array}{l}2 . \\
3\end{array}$ & Cukup & $\begin{array}{l}0 . \\
7\end{array}$ & 0.3 \\
\hline $\begin{array}{l}6 \text { Menciptakan umpan balik untuk evaluasi } \\
\text { diri }\end{array}$ & 3 & 2 & 2 & 7 & $\begin{array}{l}2 . \\
3\end{array}$ & Cukup & $\begin{array}{l}0 . \\
7\end{array}$ & 0.3 \\
\hline
\end{tabular}

Tabel 5. Rangkuman Hasil Penilaian oleh Pakar: Kelayakan Penyajian Pembelajaran

Hasil telaah dan penilaian guru terhadap buku ajar siswa disajikan dalam Tabel 6 dan Tabel 7. Hasil perhitungan rangkuman telaah dan penilaian guru terhadap aspek pembelajaran kewirausahaan terintegrasi pada buku ajar untuk siswa disajikan dalam Tabel 6. Kriteria-kriteria yang digunakan untuk melakukan telaah dan penilaian terhadap aspek pembelajaran kewirausahaan terintegrasi pada buku ajar siswa terdiri atas 5 komponen, yaitu (a) kesesuaian dengan konsep kurikulum berbasis kompetensi, (b) menekankan pada penerapan-penerapan dunia nyata di bidang kewirausahaan, (c) menunjang terlaksananya pembelajaran yang berfokus pada student-centered, (d) memberikan kemudahan dalam mengembangkan pembelajaran kewirausahaan terintegrasi, dan (e) menunjang terlaksananya pendidikan kewirausahaan terintegrasi pada Pendidikan Seni Rupa. Setiap komponen tersebut dinilai dengan rubrik dengan menggunakan skor 1 (sangat kurang) sampai dengan 4 (sangat baik).

Rerata skor kesesuaian dengan konsep kurikulum berbasis kompetensi sebesar 3,7 (sangat baik), menekankan pada penerapan-penerapan dunia nyata di bidang kewirausahaan 2,7 (baik), menunjang terlaksananya pembelajaran yang berfokus pada student-centered 3,3 (baik), memberikan kemudahan dalam mengembangkan pembelajaran kewirausahaan terintegrasi 3,3 (baik), dan menunjang terlaksananya pendidikan kewirausahaan terintegrasi pada Pendidikan Seni Rupa sebesar 3,3 (baik). Dari kelima komponen sebagai kriteria penilaian tersebut hanya aspek menekankan pada penerapan-penerapan dunia nyata di bidang kewirausahaan yang mendapat nilai dengan kategori cukup. Aspek kesesuaian dengan konsep Kurikulum Berbasis Kompetensi memperoleh skor dengan kategori sangat baik $(3,7)$, sedangkan yang lainnya berkategori baik. Dengan demikian, secara umum dapat disimpulkan bahwa pembelajaran kewirausahaan terintegrasi pada buku ajar untuk siswa adalah baik yaitu 3,2 . 
Hasil perhitungan rangkuman hasil telaah dan penilaian guru terhadap aspek pembentukan pola pikir entrepreneurial pada buku ajar untuk siswa disajikan dalam Tabel 7. Kriteria-kriteria yang digunakan untuk melakukan telaah dan penilaian terhadap aspek pembentukan pola pikir entrepreneurial pada buku ajar tersebut terdiri atas 6 komponen, yaitu (a) menumbuhkan semangat kewirausahaan, (b) membiasakan pola pikir kewirausahaan, (c) merangsang perilaku kerja kreatif dan inovatif, (d) menumbuhkan semangat daya saing, (e) mendorong perilaku dan etos kerja produktif, (f) mengembangkan kecakapan sosial. Seperti halnya pada aspek pembelajaran kewirausahaan terintegrasi, setiap komponen tersebut dinilai dengan rubrik dengan menggunakan skor 1 (sangat kurang) sampai dengan 4 (sangat baik).

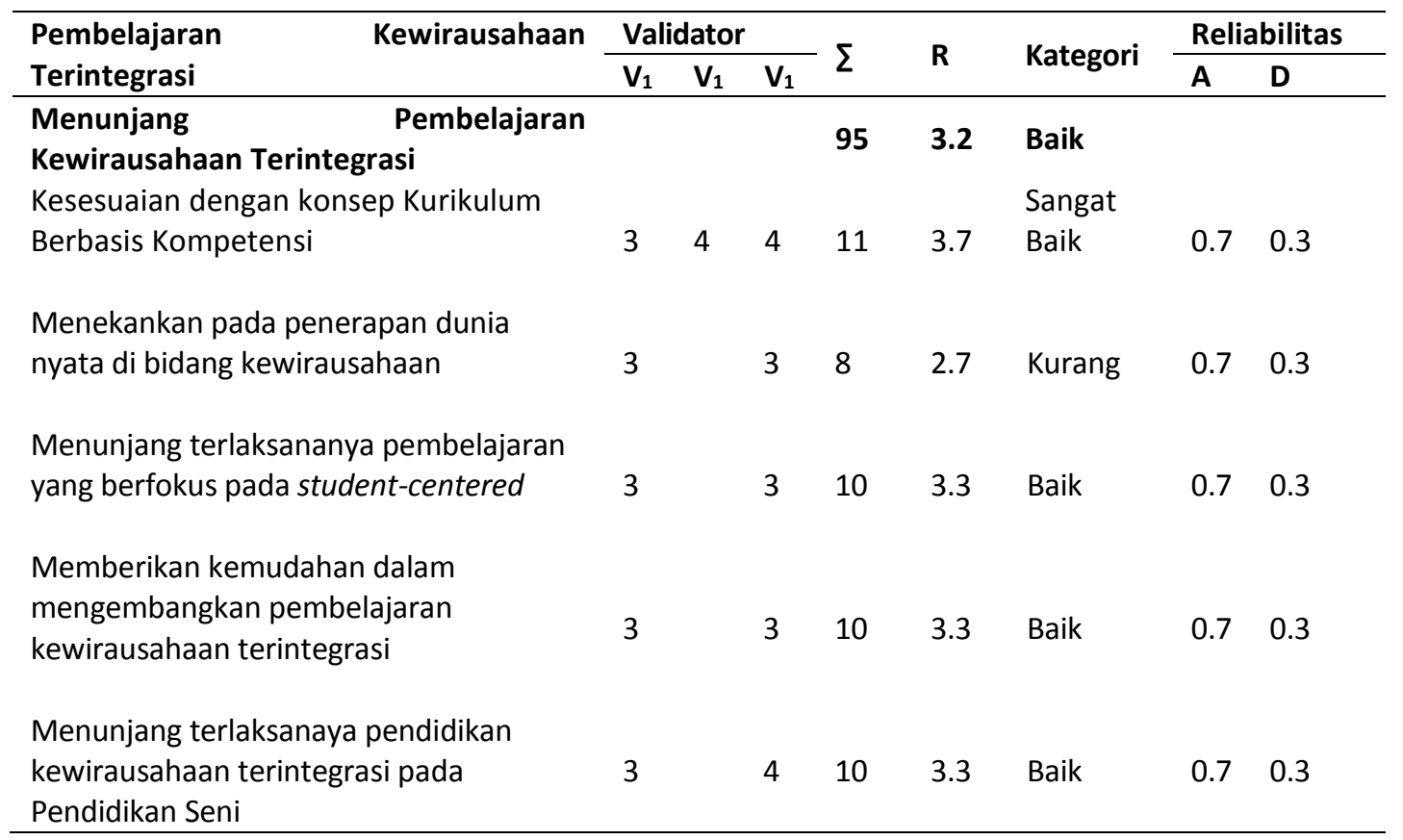

Tabel 6. Rangkuman Hasil Penilaian oleh Guru: Aspek Pembelajaran Kewirausahaan Terintegrasi

Berdasarkan Tabel 7 dapat diketahui bahwa rerata pada kriteria penilaian aspek menumbuhkan semangat kewirausahaan sebesar 3,3 (baik), membiasakan pola pikir kewirausahaan 3,0 (baik), merangsang perilaku kerja kreatif dan inovatif 3,3 (baik), menumbuhkan semangat daya saing 3,3 (baik), mendorong perilaku dan etos kerja produktif 2,7 (cukup), serta mengembangkan kecakapan sosial 2,7 (kurang). Dari 6 buah kriteria yang digunakan untuk menelaah dan menilai buku siswa hanya terdapat 1 yang cukup dan 1 yang kurang, sementara itu 4 kriteria lainnya berkategori baik. 
230 | BAHASA DAN SENI, Tahun 45, Nomor 2, Agustus 2017

\begin{tabular}{|c|c|c|c|c|c|c|c|c|}
\hline \multirow{3}{*}{ Pembentukan Pola Pikir Entrepreneurial } & \multicolumn{6}{|c|}{ Validator } & \multirow{2}{*}{\multicolumn{2}{|c|}{$\begin{array}{l}\text { Reliabilit } \\
\text { as }\end{array}$}} \\
\hline & & & & $\Sigma$ & $\mathbf{R}$ & Kategori & & \\
\hline & $V_{1}$ & $V_{1}$ & $V_{1}$ & & & & A & D \\
\hline $\begin{array}{l}\text { Menunjang Pembentukan Pola Pikir } \\
\text { Entrepreneurial }\end{array}$ & & & & 5.4 & 3.0 & Baik & & \\
\hline Menumbuhkan semangat kewirausahaan & 3 & & & ) & 3 & Baik & 0.7 & 0.3 \\
\hline Membiasakan pola pikir kewirausahaan & 3 & & & & 0 & Baik & 1.0 & 0.3 \\
\hline $\begin{array}{l}\text { Merangsang perilaku kerja kreatif } \\
\text { dan inovatif }\end{array}$ & 3 & & & ) & 3 & Baik & 0.7 & 0.3 \\
\hline Menumbuhkan semangat daya saing & 3 & & & J & 3 & Baik & 0.7 & 0.3 \\
\hline $\begin{array}{l}\text { Mendorong perilaku dan etos kerja } \\
\text { produktif }\end{array}$ & 3 & 2 & 2 & 7 & 3.3 & Cukup & 0.7 & 0.3 \\
\hline Mengembangkan kecakapan sosial & 3 & & & & 7 & Kurang & 0.7 & 0.3 \\
\hline
\end{tabular}

Tabel 7. Rangkuman Hasil Penilaian oleh Guru: Aspek Pembentukan Pola Pikir Entrepreneurial

Berdasarkan Tabel 6 dan Tabel 7 dapat disimpulkan secara umum penilaian pembentukan pola pikir entrepreneurial pada buku ajar untuk siswa mayoritas berkategori baik. Akan tetapi, aspek 'menekankan pada penerapan-penerapan dunia nyata di bidang kewirausahaan' berkategori kurang sehingga aspek ini perlu diperbaiki agar lebih nampak konteks aplikasinya pada kehidupan sehari-hari. Pada telaah buku ajar siswa aspek pembelajaran kewirausahaan terintegrasi yang dinilai mendapatkan penilaian positif dari guru-guru tersebut. Artinya, untuk seluruh aspek yang dinilai, persentase untuk mendapatkan penilaian dengan nilai 3 (baik) atau 4 (baik sekali) relatif lebih tinggi yaitu sebanyak 8 item dibandingkan persentase yang mendapatkan nilai 1(kurang) atau 2 (cukup) sebanyak 2 item. Artinya, sebagian besar aspek yang dinilai pada buku ajar siswa mendapatkan penilaian minimal 3 (baik) oleh para guru senior pengguna buku ajar tersebut.

Berdasarkan uraian tersebut, dapat dinyatakan bahwa buku ajar pendidikan seni rupa yang dikemas menurut pembelajaran entrepreneurial ini berkategori valid dan reliabel. Hal ini berdasarkan pada hasil validasi para pakar yang menunjukkan tingkat validitas sebesar 2,41 (baik) dengan reliabilitas sebesar 77,04\% (baik) dan tingkat validitas oleh guru menunjukkan tingkat validitas sebesar 3,07 (baik) dengan reliabilitas sebesar 77,03\% (baik).

Dalam uji keefektifan buku ajar, diperoleh taraf signifikan sebesar 0,035<0,05 yang berarti ada pengaruh penggunaan buku ajar yang dikembangkan terhadap hasil belajar peserta didik. Selisih rerata skor pra tes dengan pasca tes sebesar 8,11. Nilai rerata pasca tes sebesar 71, lebih baik 8,11 daripada skor rerata pra tes yaitu 62,89. Jadi terdapat perbedaan hasil belajar yang signifikan antara rerata skor pascates (yang menggunakan buku ajar entrepreneurial) dengan rerata skor prates.

Hasil pembelajaran Seni Rupa yang menggunakan buku ajar menurut pendekatan entrepreneurial bisa berbeda dengan pembelajaran biasa yang hanya berfokus pada pencapaian kompetensi menurut learning outcomes semata. Riset telah membuktikan bahwa pembelajaran entrepreneurial yang mengimplementasikan strategi entrepreneurial dalam bahan ajar seni rupa mampu memberikan nilai tambah meningkatnya kreativitas dan inovasi secara signifikan (Subhan, 2017; Wulandari, 2017). Nilai tambah adalah nilai apa yang telah terakumulasi sebagai hasil belajar dari sesuatu model pembelajaran tertentu. Sebagai model pembelajaran inovatif, model pembelajaran entrepereneurial memberikan nilai tambah pembiasaan optimalisasi kemampuan kreatif dan inovatif di samping kompetensi kurikuler sebagaimana dirumuskan dalam tujuan pembelajaran. 
Penelitian ini telah menghasilkan buku ajar Pendidikan Seni Rupa yang penyajiannya menggunakan sintaks pembelajaran entrepreneurial untuk pembangunan pola pikir entrepreneurial pada siswa. Buku ajar Pendidikan Seni Rupa tersebut memiliki spesifikasi (1) berbasis pada kompetensi, (2) berisi kompetensi-kompetensi di bidang Pendidikan Seni Rupa, (3) berpusat pada siswa, (4) strategi pembelajarannya menggunakan pembelajaran entrepreneurial menurut pola learning cycle, (5) menggunakan sintaks pembelajaran entrepreneurial yang terdiri atas (a) exploring, (b) planning, (c) doing, (d) communicating, dan (e) reflecting.

Buku ajar tersebut telah dinyatakan lulus validasi yang dilakukan oleh para pakar yang berperan sebagai validator dalam penelitian ini. Hal ini berdasarkan pada hasil validitasi pakar yang menunjukkan tingkat validitas sebesar 2,41 (baik) dengan reliabilitas sebesar $77,04 \%$ (baik). Selain itu, hasil tersebut juga didukung oleh hasil uji coba terhadap para guru pengampu mata pelajaran Pendidikan Seni pengguna buku ajar tersebut. Tingkat validitas oleh guru sebesar 3,07 (baik) dengan reliabilitas sebesar 77,03\% (baik).

Buku ajar tersebut telah terbukti efektif untuk meningkatkan hasil belajar. Dengan taraf signifikansi sebesar $0,035<0,05$ pada uji $\mathrm{t}$ dapat disimpulkan bahwa buku ajar yang dikembangkan berpengaruh secara signifikan terhadap hasil belajar peserta didik. Dengan kata lain, bahan ajar yang dirancang menurut strategi pembelajaran entrepreneurial tersebut dapat meningkatkan pola pikir entrepreneurial pada siswa. Hasil penelitian ini memiliki nilai strategis bagi pembangunan pendidikan kewirausahaan. Apalagi jika mengingat bahwa hasil penelitian ini berpotensi untuk diperluas pada bidang-bidang dan mata pelajaran-mata pelajaran lainnya pada jenis dan jenjang pendidikan yang beragam. Pengembangan bahan ajar untuk siswa dan implementasi pembelajaran entrepreneurial yang efektif pada gilirannya akan memberikan kontribusi untuk menghasilkan generasi muda yang berwawasan dan berpola pikir entrepreneurial. Pada gilirannya, ini akan dapat meningkatkan jumlah entrepreneur baru yang akan meningkatkan kesejahteraan masyarakat.

Seperti diketahui, pada era industri kreatif ini terdapat dua tantangan besar bagi negara kita yaitu meningkatkan daya saing bangsa dan mengatasi jumlah pengangguran terdidik yang semakin meningkat. Saat ini Pemerintah sedang menggalakkan industri kreatif sebagai komoditas utama dan unggulan. Pemerintah telah menetapkan tahun 2025 sebagai awal ekonomi kreatif dimana industri kreatif menjadi tulang punggung andalan bagi perekonomian Indonesia. Sementara itu, jumlah penganggur terdidik di Indonesia semakin meningkat. Pada 2008 saja jumlah penganggur lulusan Diploma I, II, dan III lebih dari 470.000 orang; lulusan sarjana yang menganggur berjumlah 409.890 orang (Ditjen Dikti, 2008).

Sejalan dengan itu, jumlah entrepreneur di Indonesia baru mencapai sekitar 0,18\% dari jumlah penduduk di Indonesia (Global Entrepreneurship Monitor, 2012). Jumlah ini jauh di bawah Singapura yang memiliki rasio enptrepreneur sejumlah 7\% dari penduduknya. Menurut McClelland (1999) suatu negara akan maju jika terdapat entrepreneur sedikitnya $2 \%$ dari jumlah penduduk mereka. Banyaknya jumlah penganggur terdidik serta rendahnya proporsi entrepreneur tersebut menunjukkan bahwa pendidikan belum mampu memberi bekal kepada peserta didik untuk siap berusaha sendiri. Dengan kata lain, pendidikan belum berhasil membangun pola pikir (mindset) dan kompetensi untuk berwirausaha.

Kewirausahaan (entrepreneurship) dalam pengertian ini mengacu pada kemampuan individu untuk mengubah ide menjadi tindakan. Ini termasuk ide-ide kreatif, inovatif, menunjukkan inisiatif dan berani mengambil risiko, serta kemampuan untuk menemukan 
peluang, merencanakan dan mengelola projek-projek tertentu dalam rangka untuk mencapai tujuan. Dalam hal ini, Kiggundu (2002) menyatakan bahwa kewirausahaan mendukung semua orang dalam kehidupan sehari-hari di rumah dan di masyarakat, membuat setiap orang untuk lebih sadar konteks pekerjaan mereka dan lebih mampu menangkap peluang, serta memberikan dasar baginya untuk membangun kegiatan komersial maupun sosial. Sejalan dengan hal tersebut, Garavan \& O'Cinneide (1994) menegaskan bahwa pembelajaran entrepreneurial adalah tentang pengembangan kompetensi seumur hidup.

\section{PENUTUP}

\section{Simpulan}

Pembelajaran entrepreneurial memberikan kontribusi bagi siswa untuk membangun daya saing yang kuat serta membantu mereka untuk memastikan sejumlah manfaat sosial yang positif. Dengan demikian, pembelajaran entrepreneurial bukan hanya soal akuisisi pengetahuan. Karena pembelajaran adalah tentang mengembangkan kemampuan untuk memiliki pola pikir dan tindakan, maka sikap dan perilaku tampaknya lebih penting daripada pengetahuan tentang bagaimana menjalankan suatu usaha (Booth, 2014. Singkatnya, pembelajaran entrepreneurial berarti mengembangkan pola pikir dan budaya melalui dan sekitar kewirausahaan. Oleh karena itu, buku ajar Pendidikan Seni Rupa harus mempertimbangkan berbagai aspek. Buku ajar Pendidikan Seni Rupa harus menggunakan sintaks pembelajaran entrepreneurial untuk pembangunan pola pikir entrepreneurial pada siswa. Buku ajar Pendidikan Seni Rupa tersebut harus berbasis pada kompetensi, berpusat pada siswa, menggunakan strategi pembelajaran entrepreneurial menurut pola learning cycle, dan menggunakan sintaks pembelajaran entrepreneurial yang terdiri atas (a) exploring, (b) planning, (c) doing, (d) communicating, dan (e) reflecting.

\section{Saran}

Pendidikan memainkan peran penting dalam pengembangan pola pikir dan budaya seperti itu, dan khususnya peran sentral yang dimainkan guru dalam proses ini. Hal ini membutuhkan tidak kurang dari perubahan besar dalam pendekatan pendidikan, menekankan pentingnya strategi pembelajaran inovatif dan penyediaan pengalaman baru dan bermakna bagi siswa. Karena itu, para guru perlu dilengkapi dengan sikap, pengetahuan, dan keterampilan yang tepat agar dapat membelajarkan siswa demi memiliki pola pikir dan tindakan entrepreneurial. Menawarkan dukungan khusus untuk guru sangat penting untuk membuat pembelajaran entrepreneurial berlangsung efektif. Dukungan tersebut antara lain berupa penyediaan model, pendekatan, strategi, metode, media, bahkan perangkat pembelajaran yang efektif untuk melengkapi misi penting tersebut. Selanjutnya, karena pembelajaran entrepreneurial adalah kompetensi transversal, maka hal itu harus tersedia bagi semua siswa dan diajarkan secara terintegrasi dengan mata-mata pelajaran bukan sebagai subjek terpisah. Jelas, implikasi dariperubahan ini akan berdampak pada peran guru secara substansial. Perubahan ini membutuhkan perubahan signifikan tentang cara guru dalam mebfampu mata pelajaran mereka, termasuk cara mereka dalam merancang buku-buku ajar. 


\section{DAFTAR RUJUKAN}

Ahlstrom, D. \& Zhujun Ding. 2014. Entrepreneurship in China: An Overview. International Small Business Journal, 32(6):610-618.

Defining Quality in Education. Working Paper Series, 2000, UNICEF. Embracing Diversity: Toolkit for Creating Inclusive, LearningFriendly Environments, 2004, UNESCO.

The 2005 EFA Global Monitoring Report: Education for All, The Quality Imperative, 2005 ,

Beckman, G.D. 2007. Adventuring' Arts Entrepreneurship Curricula in Higher Education: An Examination of Present Efforts, Obstacles and Best Practices." Journal of Arts Management, Law \& Society 37, no. 2:88-111.

Beckman, G. dan Essig, L. 2012. Arts entrepreneurship: A conversation. Artivate: A Journal of Entrepreneurship in the Arts, 1(1), 1-8.

Bolton, B. dan Thompson, J. 2005. Entrepreneurs, Talent, Temperanment, Technique, Elseveir, ButterworthHeinemann, Burlington.

Booth, S.B. 2014. A Review of Creativity and Entrepreneurship: Changing Currents in Education and Public Life. Artivate 3, no. 1:14-29.

Dyer, H.J., Gregersen, H.B., \& Christense, C.M. 2011. The Innovator's DNA, Mastering the Five Skills of Disruptive Innovators. Boston, Massacusetts: Harvard Business Publishing.

Erickson, H.L. 2002. Concept Based Curriculum, Teaching Beyond the Fact. California: Corwin Press, Inc.

Garavan, N.T. dan O'Cinneide, B. 1994. Entrepreneurship Education and TrainingProgrammes: A Review and Evaluation - Part 1. Journal of European Industrial Training, 18:3-12.

Global Entrepreneurship Monitor (GEM): http://www.gemconsortium.org

Hatten, T. 1995. Student attitudes toward entrepreneurship as affected by participation in an SBI program. Journal of Education for Business, 7(4), 224227.

Holcombe, R. 1998. Entrepreneurship and Economic Growth. Quarterly Journal of Austrian Economics 1 (2): 45-62

Kiggundu, M.N. 2002. Entrepreneurs and Entrepreneurship in Africa. Journal of Developmental Entrepreneurship, 7:Special Issue on Africa.

Kolb, A. Y. dan Kolb, D. A. 2006. A review of Multidisciplinary application of experiential learning theory in higher education. In Sims, R., and Sims, S. (Eds.). Learning styles and learning: A key to meeting the accountability demands in education. Hauppauge, NY: Nova Publishers.

McClelland, D.C. dan Winter, D.G. 1999. Motivating Economic Achievement. New York: Free Press.

McClelland, D.C. 1995. Achievement and Entrepreneurship: A Longitudinal Study. Journal of Personality and Social Psychology, 14:38992.

McMullan, W.E., Long, W.A. dan Graham, J.B. 1987. Entrepreneurship education in the nineties. Journal of Business Venturing, 2(3), 261275.

Pranata, M. 2015. Pengembangan Model Pendidikan Entrepreneurship Terintegrasi pada Pendidikan Seni Rupa untuk Membangun Karakter dan Pola Pikir Entrepreneurial bagi Peningkatan Daya Saing Bangsa di Era Industri Kreatif. Jakarta: DP2M Dikti, Laporan Penelitian Strategis Nasional Tahun 3. Tidak dipublikasikan. 
234 | BAHASA DAN SENI, Tahun 45, Nomor 2, Agustus 2017

Swedberg. 2006. The cultural entrepreneur and the creative industries: Beginning in Vienna. Journal of Cultural Economics, 30(4), 243-261. 